\title{
Effects of no-tillage management on soil biochemical characteristics in northern China
}

\author{
E. K. LIU ${ }^{1,2}$, B. Q. ZHAO ${ }^{3}$, X. R. MEI ${ }^{1,2 *}, \mathrm{H} . \mathrm{B} . \mathrm{SO}^{4}, \mathrm{~J}^{2} \mathrm{LI}^{3}$ AND X. Y. LI ${ }^{3}$ \\ ${ }^{1}$ Institute of Environment and Sustainable Development in Agriculture, The Chinese Academy of Agricultural \\ Sciences, Beijing 100081, P.R. China \\ ${ }^{2}$ Key Laboratory of Dryland Farming and Water-Saving Agriculture, Ministry of Agriculture of the People's \\ Republic of China (MOA), Beijing 100081, P.R. China \\ ${ }^{3}$ Agricultural Resources and Regional Planning, The Chinese Academy of Agricultural Sciences, \\ Beijing 100081, P.R. China \\ ${ }^{4}$ Griffith School of Engineering, Griffith University, Nathan, Q 4111, Australia \\ (Revised MS received 2 July 2009; First published online 20 November 2009)
}

\begin{abstract}
SUMMARY
Field experiments (15 years) were carried out to study the effects of no-tillage (NT) and conventional tillage (CT) management practices on the soil chemical properties, microbial biomass, soil enzymatic activities and winter wheat yield on a cinnamon soil in Shanxi, on the Chinese Loess Plateau. Compared to CT, NT increased soil organic carbon, soil total nitrogen and soil total phosphorus in the $0-100 \mathrm{~mm}$ layer by 25,18 and $7 \%$, respectively. Microbial biomass $\mathrm{C}$ and $\mathrm{N}$ contents under NT were 41 and $57 \%$ greater than under CT on the same layer. In general, higher enzymatic activities were found in the more superficial layers of soil under NT than under CT in the same layer. Winter wheat yield was c. $20 \%$ higher under NT than under CT. These findings have implications for understanding how conservation tillage practices improve soil quality and sustainability in the rainfed dryland farming areas of northern China.
\end{abstract}

\section{INTRODUCTION}

There is a large region of dryland farming in northern China, which accounts for $c .0 \cdot 56$ of the nation's total area. The dry semi-humid zone, with $500-600 \mathrm{~mm}$ annual rainfall, covers about half of the dryland area. Development of dryland farming in this zone is constrained by adverse weather, topography, water resource conditions and low fertility soils. Traditional tillage in northern China has already resulted in widespread soil degradation (Gao et al. 1999). Thus, conservation tillage systems in dryland regions of northern China were implemented by government in the 1980s with the goal of promoting long-term sustainability of agricultural ecosystems. The efficiency of conservation tillage (no-tillage (NT) or reduced tillage with residue kept) to reduce soil erosion and to improve soil quality is universally recognized. Numerous studies have shown that decreasing tillage

\footnotetext{
* To whom all correspondence should be addressed. Email: meixr@ieda.org.cn
}

intensity and increasing the amount of residues retained on the soil surface result in higher organic $\mathrm{C}$ and $\mathrm{N}$ and improved soil quality (Lal et al. 1994; Soon et al. 2001).

Soil organic matter (SOM) plays a key role in the improvement of soil physical, chemical and biological properties (Ouedraogo et al. 2007). Long-term tillage causes a rapid loss of SOM content, a decrease of soil biological activity and impairment of physical properties over time. Conservation tillage practices featuring residue cover and reduced soil disturbance have been shown to increase the SOM. Liang et al. (2007) reported that NT significantly increased the concentration of soil organic C (SOC) by $5 \cdot 6-5 \cdot 9 \%$ in the $50-200 \mathrm{~mm}$ layer on clay loam soils in the humid north-eastern part of China after 3 years. Wang et al. (2008) showed that long-term NT increased SOM by $22 \%$ at depths of $0-100 \mathrm{~mm}$ compared to traditional tillage.

Soil micro-organisms are the major protagonists of organic matter decomposition and nutrient turnover in arable soil. The microbial biomass is the living 
component of SOM and it typically comprises $0 \cdot 01-0.05$ of total organic matter content. Because of its high turnover rate, microbial $\mathrm{C}$ content can respond rapidly to changes in soil management practice (Gregorich et al. 1997). Soil enzymes are important soil components involved in the dynamics of soil nutrient transformations (Ebhin Masto et al. 2006). Enzyme activity in the soil environment is considered to be the major contributor of overall soil microbial activity and soil quality (Dick 1994; Melero et al. 2009).

Changes in soil physical and chemical properties associated with different tillage practices have been studied extensively in northern China (Luo et al. 2005; Zhou et al. 2007). In contrast, information on the biological processes, such as soil enzymatic activities, which mediate nutrient cycling and influence their acquisition during active crop growth stages, is limited. The objective of the present study was to determine the influence of NT and conventional tillage (CT) on soil chemical properties, microbial biomass and soil enzymatic activities on a dryland farming system in northern China.

\section{MATERIALS AND METHODS}

\section{Description of field experiment}

The long-term experiment was established in 1992 and was located in Linfen County, Shanxi, China $\left(111^{\circ} 05^{\prime}\right.$ to $111^{\circ} 48^{\prime} \mathrm{N}, 35^{\circ} 55^{\prime}$ to $36^{\circ} 20^{\prime} \mathrm{E}, 550-600 \mathrm{~m}$ asl). The average annual temperature is $10 \cdot 7^{\circ} \mathrm{C}$, with 180 frost free days in the area. The experimental area is characterized as semi-arid sub-tropical with a mean annual precipitation of $c .555 \mathrm{~mm}$, mostly falling between July and September. The soil is a Cinnamon Loess, low in organic matter and slightly alkaline. Under the USDA texture classification system, the soils are defined as silt loam and according to the FAO-UNESCO soil map (FAO-UNESCO 1974) the soil type is a chromic cambisol. The initial soil $\mathrm{pH}$ was 7.7 , organic matter $13.0 \mathrm{~g} / \mathrm{kg}$, total $\mathrm{N} 0.50 \mathrm{~g} / \mathrm{kg}$, total $\mathrm{P} 0 \cdot 15 \mathrm{~g} / \mathrm{kg}$ and total $\mathrm{K} 12 \mathrm{~g} / \mathrm{kg}$.

The site was established with two different treatments: CT and NT with straw cover. CT included mouldboard ploughing without residue cover. The ploughing depth was $c$. $150-200 \mathrm{~mm}$. NT with soil cover consisted of NT planting through the plant residue. The winter wheat was sown between 20 and 30 September and harvested between 1 and 10 June. A fallow period followed harvest until midSeptember, with chemical weed control applied when necessary. The treatments were laid out in a randomized block design (RBD), with a plot size of $3 \times 80 \mathrm{~m}$ and three replications. The winter wheat variety used throughout the study was Linfen 225 with a seeding rate of $225 \mathrm{~kg} / \mathrm{ha}$. Fertilizers were applied as $\mathrm{CO}\left(\mathrm{NH}_{2}\right)_{2},\left(\mathrm{NH}_{4}\right)_{2} \mathrm{HPO}_{4}$ and $\mathrm{KCl}$ to provide $150 \mathrm{~kg}$
$\mathrm{N} / \mathrm{ha}, 140 \mathrm{~kg} \mathrm{P}_{2} \mathrm{O}_{5} / \mathrm{ha}$ and $62 \mathrm{~kg} \mathrm{~K} \mathrm{~K}_{2} \mathrm{O} / \mathrm{ha}$. In each year, all chemical fertilizers were applied in one dose to the top $200 \mathrm{~mm}$ before planting. Straw returned to the soil was $c .3 \cdot 75 \mathrm{t} / \mathrm{ha}$ each year.

\section{Soil sampling}

Soil samples were taken in June 2006, after harvesting winter wheat, and were randomly collected from 10 locations in each plot using a $50 \mathrm{~mm}$ diameter coring tube. The soil was divided into layers of $0-50,50-100$, 100-200 and 200-300 $\mathrm{mm}$; respective layers from within each plot were composite. After carefully removing the surface organic materials and fine roots, each mixed soil sample was divided into two parts. One part of the soil sample was air-dried for the estimation of soil chemical properties and the other part was sieved through a $2 \mathrm{~mm}$ wide screen and immediately transferred to the laboratory for biochemical analysis. Soil fresh samples were kept at $4{ }^{\circ} \mathrm{C}$ in plastic bags for $c .1$ week to stabilize the microbiological activity disturbed and then analysed within 2 weeks.

\section{Analysis of soil chemical and biological properties}

SOM was determined by wet oxidation (Black 1965) and the proportion of organic carbon was calculated by applying the Van Bemmelen factor of 1.73 (Piper 1950). Soil total nitrogen (STN) and soil total phosphorus (STP) were measured using the method of Bao (2000). Soil microbial biomass of carbon (MBC) and microbial biomass of nitrogen (MBN) were estimated by fumigation-extraction (Vance et al. 1987). Soil enzyme activities (dehydrogenase, $\beta$-glucosidase, alkaline phosphatase and arylsulphatase) were determined by the method of Wu et al. (2006).

\section{Statistical analysis}

All statistical analyses were undertaken using SPSS 11.0 for Windows and results were expressed as mean values. Significant differences between management systems (NT and CT) were determined by a Student's $t$-test at $P<0 \cdot 05$.

\section{RESULTS SOC, STN and STP}

Soil tillage affected soil chemical properties greatly. SOC was higher under NT than under CT at 0-100 mm (Table 1). NT increased SOC content over CT by $29 \%$ in the $0-50 \mathrm{~mm}$ layer and by $21 \%$ in the 50-100 mm layer. No significant difference was found in SOC content between NT and CT treatments in the 100-200 and $200-300 \mathrm{~mm}$ layers. The SOC in NT treatment decreased sharply with increasing soil depth. 
Table 1. Soil chemical properties: mean values of soil organic carbon (SOC), soil total nitrogen (STN) and soil total phosphorus (STP) under different tillage systems at the different depths

\begin{tabular}{lllll}
\hline \hline & \multicolumn{4}{c}{ Depth (mm) } \\
\cline { 2 - 5 } Tillage treatment & $0-50$ & $50-100$ & $100-200$ & $200-300$ \\
\hline SOC (g/kg) & & & & \\
NT & 9.5 & $8 \cdot 5$ & $7 \cdot 0$ & $5 \cdot 2$ \\
CT & $7 \cdot 4$ & $7 \cdot 0$ & $6 \cdot 8$ & $5 \cdot 7$ \\
S.E.D. (D.F. =4) & 0.39 & 0.32 & $\mathrm{NS}$ & $\mathrm{NS}$ \\
STN (g/kg) & & & & \\
NT & 0.69 & 0.63 & 0.52 & 0.39 \\
CT & 0.58 & 0.54 & 0.42 & 0.35 \\
S.E.D. (D.F.=4) & 0.033 & 0.076 & $\mathrm{NS}$ & $\mathrm{NS}$ \\
STP (g/kg) & & & & \\
NT & 0.71 & 0.68 & 0.61 & 0.55 \\
CT & 0.66 & 0.64 & 0.61 & 0.55 \\
S.E.D. (D.F.=4) & 0.017 & $\mathrm{NS}$ & $\mathrm{NS}$ & $\mathrm{NS}$ \\
\hline \hline
\end{tabular}

NS, not significant $P>0 \cdot 05$.

NT, no-tillage; CT, conventional tillage.

STN showed the same trend as SOC in relation to different tillage treatments. The amount of total $\mathrm{N}$ in the $0-100 \mathrm{~mm}$ soil layer was greater under NT than under CT (Table 1). There were no significant treatment effects on total $\mathrm{N}$ in the $100-300 \mathrm{~mm}$ depths. Total $\mathrm{N}$ decreased with depth in two tillage treatments.

Compared to the CT treatment, the NT treatment increased STP in the $0-50 \mathrm{~mm}$ layer by $7.6 \%$. Differences in STP between CT and NT treatments were not significant at the other depths.

\section{Soil $M B C, M B N$ and enzymatic activities}

$\mathrm{MBC}$ and $\mathrm{MBN}$, respectively, were significantly affected by both soil depth and tillage system. MBC varied with depth from 103 to $338 \mathrm{mg} / \mathrm{kg}$ under NT and from 94 to $227 \mathrm{mg} / \mathrm{kg}$ under CT (Table 2). Microbial biomass $\mathrm{N}$ varied from 8.3 to $21 \mathrm{mg} / \mathrm{kg}$ under NT and from $8 \cdot 2$ to $13 \cdot 1 \mathrm{mg} / \mathrm{kg}$ under CT. In the $0-50$ and $50-100 \mathrm{~mm}$ soil layers, $\mathrm{MBC}$ and $\mathrm{MBN}$ were significantly higher under NT than CT. In the 0-50 mm layer, MBC and MBN were 49 and $60 \%$ higher, respectively, under NT than under CT. MBC and MBN decreased with soil depth, more so under NT. There were no significant differences below $100 \mathrm{~mm}$.

Tillage system had significant effects on soil dehydrogenase activity (Table 2 ). The dehydrogenase activity varied with depth from 8.1 to $56 \mathrm{mg} T P F / \mathrm{kg} /$ $24 \mathrm{~h}$ in the soil under NT and from 14 to $37 \mathrm{TPF} / \mathrm{kg} /$ $24 \mathrm{~h}$ under CT. NT resulted in a significant increase in
Table 2. Soil biological properties: mean values of microbial biomass carbon (MBC), microbial biomass nitrogen $(M B N)$ and enzymatic activities in soil under different tillage systems at the different depths

\begin{tabular}{|c|c|c|c|c|}
\hline \multirow[b]{2}{*}{ Tillage treatment } & \multicolumn{4}{|c|}{ Depth (mm) } \\
\hline & $0-50$ & $50-100$ & $100-200$ & $200-300$ \\
\hline \multicolumn{5}{|l|}{$\mathrm{MBC}(\mathrm{mg} / \mathrm{g})$} \\
\hline NT & 338 & 256 & 181 & 103 \\
\hline $\mathrm{CT}$ & 227 & 194 & 161 & 94 \\
\hline S.E.D. (D.F. $=4)$ & $10 \cdot 4$ & $10 \cdot 2$ & NS & NS \\
\hline \multicolumn{5}{|l|}{$\mathrm{MBN}(\mathrm{mg} / \mathrm{g})$} \\
\hline NT & 21 & 17 & 12 & 8 \\
\hline CT & 13 & 11 & 10 & 8 \\
\hline S.E.D. (D.F. $=4)$ & $2 \cdot 0$ & $1 \cdot 8$ & NS & NS \\
\hline \multicolumn{5}{|c|}{ Dehydrogenase (mg TPF $/ \mathrm{kg} / 24 \mathrm{~h}$ ) } \\
\hline NT & 56 & 37 & 26 & 8 \\
\hline $\mathrm{CT}$ & 37 & 28 & 25 & 14 \\
\hline S.E.D. (D.F. $=4)$ & $1 \cdot 4$ & $0 \cdot 6$ & NS & NS \\
\hline \multicolumn{5}{|c|}{ Alkaline phosphatase (mg PNP $/ \mathrm{kg} / \mathrm{h})$} \\
\hline NT & 413 & 328 & 300 & 295 \\
\hline CT & 320 & 267 & 303 & 271 \\
\hline S.E.D. (D.F. $=4)$ & $9 \cdot 4$ & $11 \cdot 8$ & NS & NS \\
\hline \multicolumn{5}{|c|}{$\beta$-glucosidase (mg PNP/kg/h) } \\
\hline NT & 349 & 312 & 267 & 184 \\
\hline CT & 254 & 201 & 197 & 99 \\
\hline S.E.D. (D.F. $=4)$ & $10 \cdot 5$ & $5 \cdot 9$ & $19 \cdot 8$ & $29 \cdot 1$ \\
\hline \multicolumn{5}{|c|}{ Arylsulphatase (mg PNP/kg/h) } \\
\hline NT & $32 \cdot 8$ & $26 \cdot 3$ & $23 \cdot 5$ & $19 \cdot 6$ \\
\hline $\mathrm{CT}$ & $9 \cdot 6$ & $7 \cdot 3$ & $6 \cdot 1$ & $4 \cdot 6$ \\
\hline S.E.D. (D.F. $=4)$ & $1 \cdot 26$ & $0 \cdot 65$ & $1 \cdot 63$ & $0 \cdot 53$ \\
\hline
\end{tabular}

NS, not significant $P>0 \cdot 05$.

dehydrogenase activity in the $0-100 \mathrm{~mm}$ layer; however, in the 100-300 $\mathrm{mm}$ layer there was no significant difference in dehydrogenase activity between treatments NT and CT.

Tillage treatment had a significant effect on alkaline phosphatase activity (Table 2), particularly in the 0-50 and 50-100 mm layers, where NT significantly improved alkaline phosphatase activity (by at least $22 \%$ compared to $\mathrm{CT}$ ). In the $100-300 \mathrm{~mm}$ layer, values for both treatments were similar, indicating that tillage effects on alkaline phosphatase activity were more pronounced in the topsoil.

The $\beta$-glucosidase activity varied from 184 to $349 \mathrm{mg} \mathrm{PNP} / \mathrm{kg} / \mathrm{h}$ in the soil under NT and from 99 to $254 \mathrm{mg} \mathrm{PNP} / \mathrm{kg} / \mathrm{h}$ under CT (Table 2). $\beta$-glucosidase activity was significantly influenced by tillage management. Averaged across the depths, $\beta$-glucosidase activity under NT was $48 \%$ higher than under CT.

Arylsulphatase activity varied from 20 to $33 \mathrm{mg} \mathrm{PNP} / \mathrm{kg} / \mathrm{h}$ in the soil under NT and from 4.6 to $9.6 \mathrm{mg} \mathrm{PNP} / \mathrm{kg} / \mathrm{h}$ under CT (Table 2). NT 


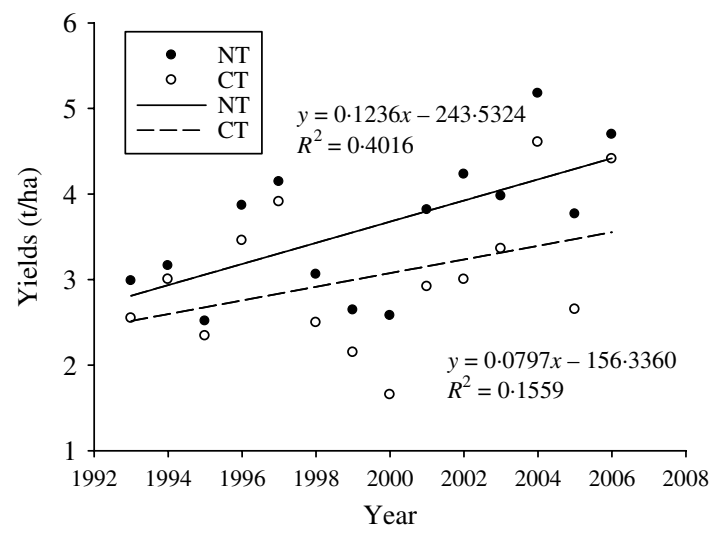

Fig. 1. Trends in yields of winter wheat for NT and CT treatments at Linfen in China. NT, no-tillage; CT, conventional tillage.

management resulted in a significant increase in arylsulphatase activity at all depths. In general, arylsulphatase activity under NT was at least three times higher than under CT.

\section{Winter wheat yield}

In general, yields of the winter wheat fluctuated widely from year to year. Although there were large fluctuations of yields with time, the mean yield of winter wheat under NT was $20 \%$ higher $(P<0.05)$ than under CT during 1993-2006 (Fig. 1). Regression analysis of yield and year for NT treatment demonstrated significant correlations. The coefficients on the time variable were positive in two treatments, but were statistically significant $(P<0.05)$ only in the NT treatment. Figure 1 also demonstrated the relatively small difference between treatments in the first 5 years, and much greater difference in the subsequent 9 years. Considering these subsequent 9 years on their own, the mean yield of NT winter wheat was $24.5 \%$ greater than that from ploughed plots.

\section{DISCUSSION}

SOC contents provide a measurement of SOM status. In the present study, soil under NT had higher SOC content than soil under CT. This increase is particularly important in the north of China, where the levels of organic matter in the semi-arid agricultural soils are low. The greater SOC developed under NT may have been a result of the reduced contact of crop residues with soil. Surface residues tend to decompose more slowly than soil-incorporated residues, because of greater fluctuations in surface temperature and moisture and reduced availability of nutrients to microbes colonizing the surface residue (Schomberg et al. 1994). For the CT, when soils are ploughed, some standing wheat stubble is moved into deeper soil layers $(100-300 \mathrm{~mm})$; CT incorporates residues into a larger volume of soil and therefore increases the rates of organic matter decomposition and $\mathrm{C}$ mineralization (Salinas-García et al. 2002), by increasing the contact between soil micro-organisms and crop residues (Henriksen \& Breland 2002) and by disruption of SOM protected within aggregates (Six et al. 2000).

Differences in STN among tillage systems are in agreement with other studies (Embacher et al. 2007; Wang et al. 2008), who demonstrated that STN decreased with increasing soil depth. The higher total N found in the present study under NT was also consistent with the findings of other researchers (Torbert \& Reeves 1995; Thomas et al. 2007). Increased total $\mathrm{N}$ apparently resulted from the increased accumulation of crop residues near the soil surface with NT systems. Total $\mathrm{N}$ is known to be enhanced by increasing SOM content (Salinas-García et al. 2002).

STP was higher under NT than under CT to a depth of $50 \mathrm{~mm}$. Long-term NT management commonly leads to a stratification of $\mathrm{P}$ in soils (Zibilske et al. 2002). Phosphorus stratification in the present experiment suggests a changing status of $\mathrm{P}$ fertility due to tillage effects. Rhoton (2000) also found a higher amount of $\mathrm{P}$ in the $25 \mathrm{~mm}$ depth under NT. The apparent 'mining' of $\mathrm{P}$ from lower soil depths and retention in upper depths in conservation-tillage systems is probably due to immobilization of $\mathrm{P}$, which promotes the organic $\mathrm{P}$ cycle, and to the chelation effect of organic compounds on soluble P (Zibilske et al. 2002).

The soil microbial biomass, which represents about $0.01-0.05$ of total SOC, can provide an effective early warning of the improvement or deterioration of soil quality as a result of different management practices (Powlson et al. 1987). In the present study, MBC and $\mathrm{MBN}$ were higher under NT than under CT to a depth of $100 \mathrm{~mm}$ and decreased with further soil depth, more so under NT. This decrease, however, was least evident in conventional soils and probably resulted from the incorporation and mixing of crop residues within the ploughing layer. In contrast, higher surface soil microbial biomass concentrations with NT may be due to the accumulation of crop residues at the soil surface (Salinas-García et al. 2002). The observed increase in microbial biomass with NT is similar to that reported by Wright et al. (2005), who found that microbial biomass $\mathrm{C}$ in the surface layer of NT soils averaged $80 \%$ higher than in ploughed soils. The present results of greater stratification of soil MBC under NT than under CT are in accordance with several other studies (Feng et al. 2003).

Since dehydrogenase activity is only present in viable cells, it is thought to reflect the total range of oxidative activity of soil microflora and consequently 
may be considered to be a good indicator of microbial activity (Nannipieri et al. 1990). In the top soil $(0-100 \mathrm{~mm})$, dehydrogenase was significantly higher under NT, indicating a consistent improvement of soil quality under NT. Other authors have reported similar results under NT or CT under semi-arid conditions (Madejón et al. 2007).

The phosphatases are a broad group of enzymes that hydrolyses esters and anhydrides of phosphoric acid. Alkaline phosphatase activity was mainly influenced by application of $\mathrm{P}$, demonstrating that this enzyme was mainly influenced by single nutrient elements in the dryland soil. Hence, it may be used as an indicator of the status of soil $P$ supplies, but not as an indicator of the comprehensive fertility of the soil. Long-term tillage had a significant effect on alkaline phosphatase activity, particularly in the $0-50$ and $5-100 \mathrm{~mm}$ soil layers, where NT significantly $(P<0 \cdot 05)$ improved alkaline phosphatase by over $25 \%$ compared to $\mathrm{CT}$. In the $100-300 \mathrm{~mm}$ layer, there was no significant difference in alkaline phosphatase between treatments NT and CT. Omidi et al. (2008) showed that phosphatase activity in soils under NT management was greater than under conventional management. The increase in activity of hydrolase enzyme might be due to higher levels of intracellular and/or extracellular enzymes, immobilized by recalcitrant humic moieties (Nannipieri 1994).

In the $0-300 \mathrm{~mm}$ soil layers, $\beta$-glucosidase was significantly $(P<0.05)$ higher under NT than under CT. $\beta$-glucosidase, an enzyme already reported as an early indicator of changes in soil properties induced by tillage systems (Ekenler \& Tabatabai 2003), catalyses the hydrolysis of various $\beta$-glucosides during the decomposition of organic materials. This could indeed explain the increase in $\beta$-glucosidase initially observed as a result of NT with straw cover treatment.

Arylsulphatase is the enzyme that is involved in mineralization of ester sulphate in soils, and opinions on its activity have varied widely in the literature in relation to soil properties and management (Gupta \& Germida 1988; Bandick \& Dick 1999). The greater arylsulphatase activity under NT may reflect the increase of fungal biomass because arylsulphatase is strongly correlated with ergosterol, which is almost exclusively found in fungi (Newell et al. 1987). Furthermore, fungi have up to 0.42 of their $\mathrm{S}$ as ester sulphate, which is the substrate for arylsulphatase, while bacteria have around $0 \cdot 10$ ester sulphate-S (Saggar et al. 1981).

Tillage system did affect winter wheat yield. The positive yield response of winter wheat to NT was also found by Hemmat \& Eskandari (2004). He et al. (2009) and Su et al. (2007) reported that NT could maintain crop productivity in northern China. This significant improvement under NT management was attributed to increased soil water storage and organic matter status. In semi-arid areas with frequent droughts, NT is of particular importance for stabilizing and improving crop yields.

The main conclusions from the present work are that NT management practices in the semi-arid area of the north China improved the quality of soil chemical properties, microbial biomass and soil enzymatic activities. SOC, STN and STP in the topsoil $(0-100 \mathrm{~mm})$ were greater under NT than under CT. The NT system was more effective in improving soil biochemical quality than the CT system. The beneficial effects of conservation agriculture on soil quality were more noticeable in the superficial layer $(0-100 \mathrm{~mm})$ than in the deeper layers $(<100 \mathrm{~mm})$. It is suggested that NT may be successful in maintaining sustainability and improving soil biological properties.

This study was partially supported by the National Basic Research Program of China (973 Program) (No. 2007CB109305), the 11th five-year plan of National Key Technologies R\&D Program (No. 2006BAD29B01 and No. 2006BAD29B02), the Important National Science and Technology Specific Projects (No. 2008ZX07105-002) and the China Postdoctoral Science Foundation funded project (No. 20080440461). We are grateful to Professor Gao Huanwen and Li Hongwen for providing a valuable long-term NT platform for this research.

\section{REFERENCES}

Bandick, A. K. \& Dick, R. P. (1999). Field management effects on soil enzyme activities. Soil Biology and Biochemistry 31, 1471-1479.

BAo, S. D. (2000). Soil and Agricultural Chemistry Analysis (in Chinese). Beijing, China: China Agricultural Press.

Black, C. A. (1965). Methods of Soil Analysis. Part 2: Chemical and Microbiological Properties. Madison, WI: ASA.

Dick, R. P. (1994). Soil enzyme activity as indicators of soil quality. In Defining Soil Quality for a Sustainable Environment (Eds J. W. Doran, D. Coleman, D. Bezdicek
\& B. Stewart), pp. 107-124. Soil Science Society of America (SSSA) Special Publication No. 35. Madison, WI: SSSA and ASA.

Ebhin Masto, R., Chhonkar, P. K., Singh, D. \& Patra, A. K. (2006). Changes in soil biological and biochemical characteristics in a long-term field trial on a subtropical inceptisol. Soil Biology and Biochemistry 38, 1577-1582.

Ekenler, M. \& Tabatabai, M. A. (2003). Effects of liming and tillage systems on microbial biomass and glycosidases in soils. Biology and Fertility of Soils 39, 51-61. 
Embacher, A., Zsolnay, A., Gattinger, A. \& Munch, J. C. (2007). The dynamics of water extractable organic matter (WEOM) in common arable topsoils: I. Quantity, quality and function over a three year period. Geoderma 139, $11-22$.

FAO-UNESCO. (1974). Soil Map of the World. Paris: UNESCO.

Feng, Y., Motta, A. C., Reeves, D. W., Burmester, C. H., van Santen, E. \& Osborne, J. A. (2003). Soil microbial communities under conventional-till and no-till continuous cotton systems. Soil Biology and Biochemistry 35, 1693-1703.

Gao, H. W., Li, H. W. \& Chen, J. D. (1999). Research on sustainable mechanized dryland farming. Agricultural Research in the Arid Areas 1, 57-62.

Gregorich, E. G., Carter, M. R., Doran, J. W., Pankhurst, C. E. \& Dwyer, L. M. (1997). Biological attributes of soil quality. In Soil Quality for Crop Production and Ecosystem Health (Eds E. G. Gregorich \& M. R. Carter), pp. 81-113. Amsterdam: Elsevier.

Gupta, V. V. S. R. \& Germida, J. J. (1988). Distribution of microbial biomass and its activity in different soil aggregate size classes as affected by cultivation. Soil Biology and Biochemistry 20, 777-786.

He, J., Kuhn, N. J., Zhang, X. M., Zhang, X. R. \& Li, H. W. (2009). Effects of 10 years of conservation tillage on soil properties and productivity in the farming-pastoral ecotone of Inner Mongolia, China. Soil Use and Management 25, 201-209.

Hemmat, A. \& Eskandari, I. (2004). Conservation tillage practices for winter wheat-fallow farming in the temperate continental climate of northwestern Iran. Field Crops Research 89, 123-133.

Henriksen, T. M. \& Breland, T. A. (2002). Carbon mineralization, fungal and bacterial growth, and enzyme activities as affected by contact between crop residues and soil. Biology and Fertility of Soils 35, 41-48.

Lal, R., Mahboubi, A. A. \& Fausey, N. R. (1994). Longterm tillage and rotation effects on properties of a central Ohio soil. Soil Science Society of America Journal 58, 517-522.

Liang, A. Z., Zhang, X. P., FAnG, H. J., Yang, X. M. \& Drury, C. F. (2007). Short-term effects of tillage practices on organic carbon in clay loam soil of Northeast China. Pedosphere 17, 619-623.

Luo, Z. Z., Huang, G. B. \& Zhang, G. S. (2005). Effects of conservation tillage on bulk density and water infiltration of surface soil in semi-arid area of west Loess Plateau. Agricultural Research in the Arid Areas 23, 7-11.

Madejón, E., Moreno, F., Murillo, J. M. \& Pelegrín, F. (2007). Soil biochemical response to long-term conservation tillage under semi-arid Mediterranean conditions. Soil and Tillage Research 94, 346-352.

Melero, S., Vanderlinden, K., Carlos Ruiz, K. \& MAdEJón, E. (2009). Soil biochemical response after 23 years of direct drilling under a dryland agriculture system in southwest Spain. Journal of Agricultural Science, Cambridge 147, 9-15.

NANNiPIERI, P. (1994). The potential use of soil enzymes as indicators of productivity, sustainability and pollution. In Soil Biota: Management in Sustainable Farming Systems (Eds C. E. Pankhurst, B. M. Doube, V. V. S. R. Gupta \& P. R. Grace), pp. 238-244. Melbourne: Commonwealth Scientific and Industrial Research Organisation (CSIRO).
Nannipieri, P., Greco, S. \& Ceccanti, B. (1990). Ecological significance of the biological activity in soil. In Soil Biochemistry, Vol. 6 (Eds J. M. Bollag \& G. Stotzky), pp. 293-355. New York: Marcel Dekker.

Newell, S. Y., Miller, J. D. \& Fallon, R. D. (1987). Ergosterol content of salt marsh fungi: effect of growth conditions and mycelial age. Mycologia 79, 688-695.

Omidi, H., Tahmasebi, Z., Torabi, H. \& Miransari, M. (2008). Soil enzymatic activities and available $\mathrm{P}$ and $\mathrm{Zn}$ as affected by tillage practices, canola (Brassica napus L.) cultivars and planting dates. European Journal of Soil Biology 44, 443-450.

Ouedraogo, E., Mando, A., Brussaard, L. \& Stroosnijder, L. (2007). Tillage and fertility management effects on soil organic matter and sorghum yield in semiarid West Africa. Soil and Tillage Research 94, 64-74.

PIPER, C. S. (1950). Soil and Plant Analysis. Adelaide: University of Adelaide Press.

Powlson, D. S., Brooks, P. C. \& Christensen, B. T. (1987). Measurement of soil microbial biomass provides an early indication of changes in total soil organic matter due to straw incorporation. Soil Biology and Biochemistry 19, 159-164.

Rнотол, F. E. (2000). Influence of time on soil responses to no-till practices. Soil Science Society of America Journal 64, 700-709.

Saggar, S., Bettany, J. R. \& Stewart, J. W. B. (1981). Measurement of microbial sulfur in soil. Soil Biology and Biochemistry 13, 493-498.

Salinas-García, J. R., Velázquez-García, J. J., GallardoValdez, M., Díaz-Mederos, P., Caballero-Hernández, F., Tapia-Vargas, L. M. \& Rosales-Robles, E. (2002). Tillage effects on microbial biomass and nutrient distribution in soils under rain-fed corn production in central-western Mexico. Soil and Tillage Research 66, $143-152$.

Schomberg, H. H., Steiner, J. L. \& Unger, P. W. (1994). Decomposition and nitrogen dynamics of crop residues: residue quality and water effects. Soil Science Society of America Journal 58, 372-381.

Six, J., Elliott, E. T. \& Paustian, K. (2000). Soil macroaggregate turnover and microaggregate formation: a mechanism for $\mathrm{C}$ sequestration under no-tillage agriculture. Soil Biology and Biochemistry 32, 2099-2103.

Soon, Y. K., Clayton, G. W. \& Rice, W. A. (2001). Tillage and previous crop effects on dynamics of nitrogen in a wheat-soil system. Agronomy Journal 93, 842-849.

Su, Z. Y., Zhang, J. S., Wu, W. L., CaI, D. X., Lv, J. J., Jiang, G. H., Huang, J., Gao, J., Hartmann, R. \& Gabriels, D. (2007). Effects of conservation tillage practices on winter wheat water-use efficiency and crop yield on the Loess Plateau, China. Agricultural Water Management 87, 307-314.

Thomas, G. A., Dalal, R. C. \& Standley, J. (2007). No-till effects on organic matter, $\mathrm{pH}$, cation exchange capacity and nutrient distribution in a Luvisol in the semi-arid subtropics. Soil and Tillage Research 94, 295-304.

Torbert, H. A. \& Reeves, D. W. (1995). Interactions of traffic and tillage applied to cotton on $\mathrm{N}$ movement below the root zone of a subsequent wheat crop. Soil and Tillage Research 33, 3-16. 
Vance, E. D., Brookes, P. C. \& Jenkinson, D. S. (1987). An extraction method for measuring soil microbial biomass C. Soil Biology and Biochemistry 19, 703-707.

Wang, Q. J., Bai, Y.H., Gao, H. W., He, J., Chen, H. Chesney, R. C., Kuhn, N. J. \& Li, H. W. (2008). Soil chemical properties and microbial biomass after 16 years of no-tillage farming on the Loess Plateau, China. Geoderma 144, 502-508.

Wright, A. L., Hons, F. M. \& Matocha, J. E. (2005). Tillage impacts on microbial biomass and soil carbon and nitrogen dynamics of corn and cotton rotations. Applied Soil Ecology 29, 85-92.
Wu, J. S., Lin, Q. M., HuAng, Q. Y. \& XIAo, H. A. (2006). Soil Microbial Biomass: Methods and Application. Beijing, China: Weather Press.

Zhou, H., Lu, Y.Z., YANG, Z. C. \& Li, B. G. (2007). Influence of conservation tillage on soil aggregates features in North China Plain. Agricultural Sciences in China 6, 1099-1106.

Zibilske, L. M., Bradford, J. M. \& Smart, J. R. (2002). Conservation tillage induced changes in organic carbon, total nitrogen and available phosphorus in a semi-arid alkaline subtropical soil. Soil and Tillage Research 66, 153-163. 